\title{
Horizontal Stratification of the Sand Fly Fauna (Diptera: Psychodidae) in a Transitional Vegetation between Caatinga and Tropical Rain Forest, State of Bahia, Brazil
}

\author{
Artur Gomes Dias-Lima/ ${ }^{+}$, Maria Lenise Silva Guedes*, Italo A Sherlock
}

Laboratório de Parasitologia e Entomologia, Centro de Pesquisas Gonçalo Moniz-Fiocruz, Rua Valdemar Falcão 121, 40295-001

Salvador, BA, Brasil *Departamento de Botânica, Instituto de Biologia, Universidade Federal da Bahia, Salvador, BA, Brasil

A study about the horizontal stratification of the sand fly fauna in two distinct ecosystems, caatinga area, endemic for visceral leishmaniasis, and the tropical rain forest area, endemic for cutaneous leishmaniasis, was performed in the state of Bahia, Brazil. Lutzomyia longipalpis was predominant in the caatinga, and following it came the species L. capixaba and L. oswaldoi. In the tropical rain forest other species were found, such as $\mathrm{L}$. intermedia, L. migonei, L. whitmani, L. yuilli, L.fischeri, L. damascenoi, L. evandroi, L. monticola, and L. lenti. It was found that the geographical limits of the vector species of visceral and cutaneous leishmaniasis are clearly defined by the biological and phytogeographic characteristics.

Key words: sand fly fauna - horizontal stratification - phytogeography - leishmaniasis - Lutzomyia longipalpis Lutzomyia whitmani

The leishmaniases in Brazil are included among the main parasitic diseases that affect humans. Bahia is presently the Brazilian state with the higher incidence of reported cases of American visceral leishmaniasis (AVL), also being one of the first in number of cases of American cutaneous leishmaniasis (ACL) (Funasa 2002a, b). In this state, Jequié and Jitaúna, important districts of AVL and ACL are respectively in areas of caatinga and Atlantic Forest, occupying, in part, transition areas of both types of vegetation. Therefore, despite being geographically close, the area of the city of Jequié basically has a caatinga vegetation, whilst in Jitaúna, the vegetation characteristics are distinct, being of mainly tropical rain forest, included in the domains of the Atlantic Forest.

According to Sherlock et al. (1996) two species of leishmanias were found in these municipal districts: the Leishmania chagasi Cunha \& Chagas, 1937 transmitted by Lutzomyia longipalpis (Lutz \& Neiva, 1912), and the Leishmania braziliensis Vianna, 1911, probably transmitted by the species Lutzomyia whitmani (Antunes \& Coutinho, 1939), Lutzomyia intermedia (Lutz \& Neiva, 1912), and Lutzomyia migonei (França, 1920).

Despite the existence of various studies about the sand fly fauna in many states of Brazil, these are generally restricted, involving only a single type of phytogeographic zone. Few are the studies relating the species of sand flies and phytogeographic succession.

However, in the state of Maranhão, that comprises areas of transition between the humid Amazon Forest and the caatinga, Rebelo et al. (1999) realized surveys about

This work was supported by Fiocruz, CNPq and Capes. ${ }^{+}$Corresponding author. Fax: $+55-71-356.2155$. E-mail: alima@cpqgm.fiocruz.br.

Received 20 December 2002

Accepted 9 July 2003 the sand flies in areas of ACL and AVL, respectively. Ribeiro and Missawa (2002) researched in the state of Mato Grosso the spatial distribution of the sand flies in an area of Amazon Forest, savanna and Marsh Land. In the last two ecosystems, the presence of L. longipalpis and Lutzomyia cruzi (Mangabeira, 1938) was strong. In Normandia, state of Roraima, in a caatinga area known in the region as Lavrados, Cabanillas (1999) found an abundant quantity of $L$. longipalpis, while studying the eco-epidemiological aspects of the visceral leishmaniasis. In the south of the state, in areas of Amazon Forest, this species was not found.

In Santarém, in the state of Pará, a high density of $L$. longipalpis was found in the savanna, despite being surrounded by the Amazon Forest (Senra et al. 1986).

The L. longipalpis has been associated with the dry and semi-dry zones in rural and urban areas, more frequently found in domestic animal shelters, although it is also numerous inside the houses (Deane \& Deane 1962, Sherlock \& Guitton 1969, Galati et al. 1997). The specie is common in not too humid and mountainous places, with an abundance of superficial rocks. It is absent in areas of humid forests (Deane \& Deane 1962, Forattini 1992).

The beginning of the devastation of the Atlantic Forest probably dates from 1500, at the start of the Brazilian colonization by the Portuguese. The agricultural expansion, the urban occupation and the industrial development in the state of Bahia, until the 20th century, caused the diminution of the vegetation resources (Instituto Socioambiental 2001).

The human intervention in natural environments, both for the extraction of wood and/or for the cultivation of cocoa plant Theobroma cacao L. and pastures, was intensified in the last few decades, radically modifying the vegetation cover. In the same way, the caatinga has also suffered an accentuated degradation. These environmental alterations caused modifications in the vegetation patterns and composition of the sand fly fauna. 
Therefore, an entomological investigation on the leishmaniases vectors could provide valuable information about the spatial distribution of the important sand flies species and define the risk areas of transmission of the disease, safely guiding the control programs.

The study of the horizontal stratification of the sand fly fauna in a transition area between caatinga and tropical rain forest is of great importance for the understanding of the ecoepidemiology of leishmaniases.

\section{MATERIALS AND METHODS}

For the comparative study of the sand fly fauna, an area between the municipal districts of Jequié and Jitaúna, in the state of Bahia, with transitional vegetation, was chosen, in the two distinct ecosystems: caatinga, endemic for AVL and tropical rain forest, endemic for ACL.

From 1998 to 2002, alongside the motorway that links the municipal districts of Jequié and Jitaúna, where the areas above mentioned are found, CDC light traps (Hausher's Machine Works ${ }^{\circledR}$, New Jersey, US) were placed. It were also realized captures with Shannon trap with light, Damascenos' trap, and Disney trap baited with hamsters (Mesocricetus auratus). Direct inspections with hand light in the dwellings and other resting sites of sand flies were also performed to manually catch of the vectors with the Castro's aspirator.

The sand flies captured were chemically prepared, bathed in Canadian balsam, identified and classified according to Young and Duncan (1994).

Study areas - The municipal districts of Jequié and Jitaúna are situated in the southeast of the state of Bahia (Fig. 1). These are located in a plain, intermingled with small hills and higher slopes up to $600 \mathrm{~m}$ high. As said before, these comprise a transitional flora between caatinga and tropical rain forest.

The climate is semi-dry, characterized by the irregularity of the pluviometric precipitation, with an annual index of $500 \mathrm{~mm}$ in the caatinga and semi-humid tropical, which reaches $1100 \mathrm{~mm}$ in the forest (Radambrasil 1981).

In the municipal district of Jequié (1351'50' S/ $40^{\circ} 04^{\prime} 54^{\prime \prime} \mathrm{W}$ ), because of the devastation, high trees are very scarce, predominating the lower vegetation of the caatinga (Fig. 2).

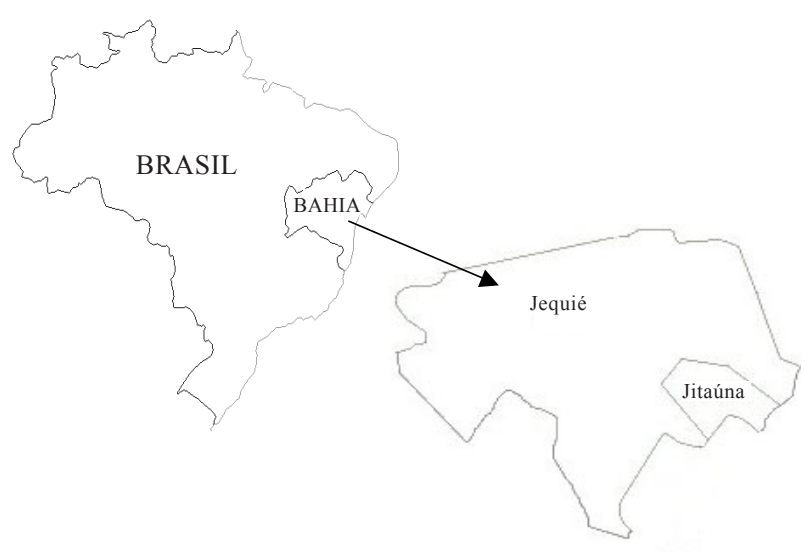

Fig. 1: maps of localization of the municipal districts of Jequié and Jitaúna, in the state of Bahia, Brazil.
There are two well defined seasons: one rainy and another dry. The dry season usually extends from September to December and the rains fall ordinarily from January to March, being the intermediary months of irregular rains and cooler climate. Besides the pluvial precipitation being too low, this zone periodically suffers from draughts (Sherlock \& Santos 1964). The climate varies with the seasons, and the maximum registered temperature was $36^{\circ} \mathrm{C}$ and minimum of $12^{\circ} \mathrm{C}$.

The caatinga is a xeric vegetation, always associated with the deciduous plants, frequently thorny vegetation represented by cactus and bromeliads (Fernandes 1998). Therefore, in the majority of the semi-dry region, the existing vegetation is constituted of secondary vegetation, resulting from the predatory activities of humans.

Jitaúna is located at $13^{\circ} 57^{\prime} 51^{\prime} \mathrm{S} / 39^{\circ} 57^{\prime} 15^{\prime} \mathrm{W}$, in mountainous areas and high slopes, having a vegetation of the tropical rain forest, included in the domains of the Atlantic Forest (Fig. 3). Nowadays, the existence of intense forest devastation is observed, with falling of trees and clearance of ground by fire for farming, such as cocoa plantations and pasture areas. The climate is hot and humid, with a pluvial precipitation of around $1100 \mathrm{~mm}$ and temperature oscillating between $16^{\circ}$ and $26^{\circ} \mathrm{C}$ (Sherlock \& Santos 1964). The residencies are located sparsely in small farms, generally surrounded by open fields.

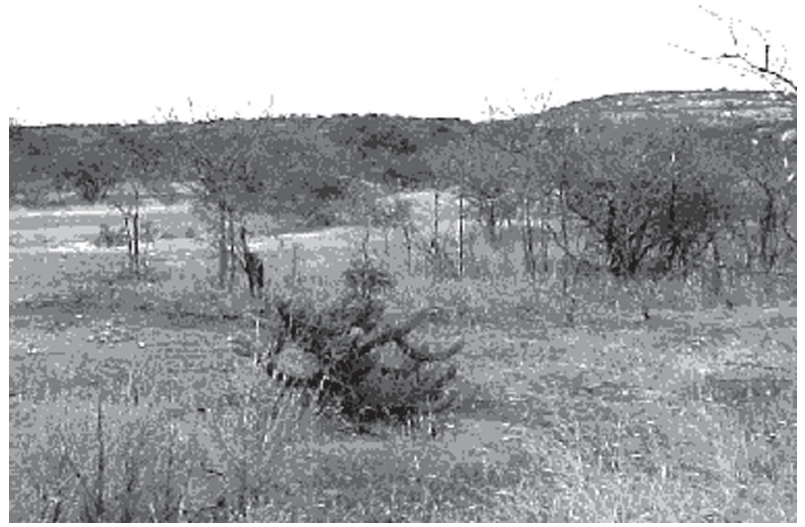

Fig. 2: caatinga vegetation, found in the municipal district of Jequié, state of Bahia, Brazil.

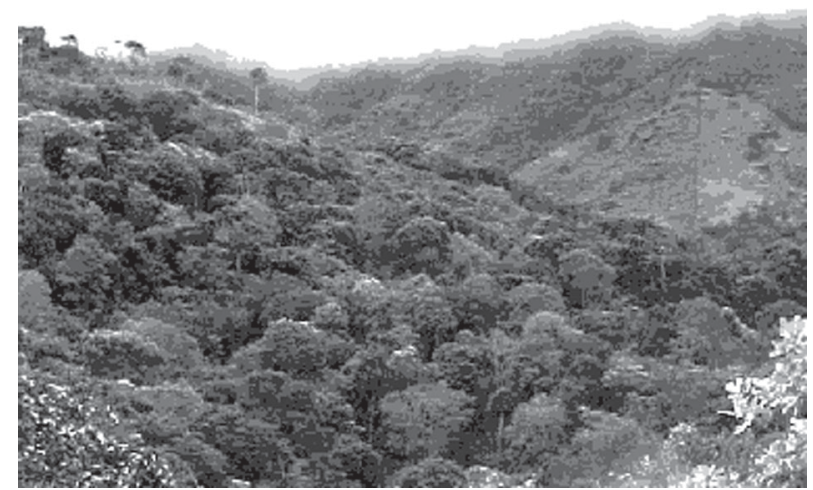

Fig. 3: tropical rain forest, found in the municipal district of Jitaúna, state of Bahia, Brazil. 
The South Atlantic Forest area and part of the southeast of Bahia have arborous formation with characteristics similar to the Amazon Forest, and is distributed around the proximities of the littoral zone (Novaes \& José 1992).

TABLE

Sand fly species collected in different phytogeographic zones, caatinga, anthropic areas, and tropical rain forest, state of Bahia, Brazil

\begin{tabular}{lccc}
\hline Species & Caatinga & $\begin{array}{c}\text { Anthropic } \\
\text { areas }\end{array}$ & $\begin{array}{c}\text { Tropical } \\
\text { rain forest }\end{array}$ \\
\hline Lutzomyia longipalpis & 470 & 96 & 0 \\
Lutzomyia capixaba & 3 & 22 & 0 \\
Lutzomyia oswaldoi & 2 & 5 & 0 \\
Lutzomyia shannoni & 0 & 2 & 0 \\
Lutzomyia whitmani & 0 & 0 & 2209 \\
Lutzomyia intermedia & 0 & 0 & 167 \\
Lutzomyia yuilli yuilli & 0 & 0 & 33 \\
Lutzomyia evandroi & 0 & 0 & 17 \\
Lutzomyia monticola & 0 & 0 & 14 \\
Lutzomyia damascenoi & 0 & 0 & 8 \\
Lutzomyia lenti & 0 & 0 & 6 \\
Lutzomyia fischeri & 0 & 0 & 4 \\
Lutzomyia migonei & 0 & 0 & 3 \\
\hline Total & 475 & 123 & 2461 \\
\hline
\end{tabular}

$a$ : presence of traces of the caatinga vegetation and deforested areas for pastures

\section{RESULTS}

In the caatinga area, municipality of Jequié, the sand fly fauna was composed by L. longipalpis, Lutzomyia capixaba Dias, Falcão \& Silva, 1987 and Lutzomyia oswaldoi (Mangabeira, 1942), vectors of Sauroleismania among lizards (Table).

At the municipal district of Jitaúna, the sand flies fauna is diversified, however it does not include L. longipalpis. Other species are present, such as: L. whitmani; $L$. intermedia; L. migonei; Lutzomyia yuilli Young \& Porter, 1972; Lutzomyia fischeri (Pinto, 1926); Lutzomyia damascenoi (Mangabeira, 1942); Lutzomyia evandroi (Costa Lima, 1932); Lutzomyia monticola (Costa Lima, 1932); and Lutzomyia lenti (Mangabeira, 1938) (Table).

Among the ecosystems mentioned, caatinga and tropical rain forest, in the pasture areas with traces of the vegetation of caatinga, L. longipalpis, L. capixaba and L. oswaldoi, typical species of the dry areas were registered. In the pasture areas with traces of tropical rain forest, besides the three species above mentioned, it was also registered the presence of Lutzomyia shannoni (Dyar, 1925).

\section{DISCUSSION}

Studying the ecology of the sand flies in the municipality of Jitaúna and Itagi, Bahia, a tropical rain forest area, where ACL occurred, Sherlock et al. (1996) found 13 species of sand flies, with predominance of $L$. whitmani $(91 \%)$, followed by the L. intermedia $(4.8 \%)$. Other species registered were: L. yuilli yuilli; L. evandroi;
L. monticola; L. (Pintomyia) sp.; L.damascenoi; L. lenti; L. fischeri; L. capixaba; L. oswaldoi; L. migonei; and Lutzomyia schreiberi Martins, Falcão \& Silva, 1955. In the same way, in the present work, L. whitmani was also predominant $(89.8 \%)$, and except for L. shannoni, 12 species were also found, as the results obtained by Sherlock et al. (1996).

In Ilhéus, south of Bahia, Azevedo et al. (1996), studying a focus of ACL in an area of Atlantic Forest, found 11 species of sand flies, with the predominance of L. whitmani, followed by L. migonei, L. schreiberi, $L$. intermedia, L. yuilli yuilli, L. fischeri, and L. shannoni, which were also present in our area of tropical rain forest, where the L. longipalpis did not exist.

Vexenat et al. (1986), in Três Braços, in the south of Bahia, an area of identical forest vegetation to that above mentioned, and endemic for ACL, registered 30 species of sand flies, where the L. whitmani was predominant within the peripheral residential area close to the forest, followed by $L$. ayrozai. It was also not also registered the presence of $L$. longipalpis in this area.

These results confirm the association between the $L$. whitmani, vector of ACL, and the ecosystems of the tropical rain forest. The $L$. longipalpis, together with $L$. capixaba, L. oswaldoi and L. schreiberi, are associated to the caatinga areas, to those which have remains of caatinga, and finally in those areas of pastures. This way, a clear demarcation of the geographic limits of sand flies species, vectors of AVL and ACL was demonstrated, according to the type of vegetation.

In Bahia, the Atlantic Forest was frequently devastated so that the cocoa could be planted under the shade of the trees. This type of the agricultural and forestal system favours the development of the cocoa culture, besides preserving a great part of the native forest, especially the high trees. In this way, humans are always in touch with a propitious environment for the transmission of ACL, be it while in sowing and growing activities, or in their own domiciles, normally in the periphery of the forest.

The ACL is a disease of an essentially focal transmission, and its dynamics is differentiated among the places of occurrence due to the variables related to the parasites, to the vectors, the ecosystems and the social processes of production and use of the soil. Among the predominant forestal ecosystems and the species vectors of ACL are included the tropical rain forest with the presence of $L$. wellcomei, $L$. intermedia, L. umbratilis and L. whitmani, a seasonal forest and tension areas between the tropical rain forest and caatinga with $L$. whitmani (Funasa 2002b).

L. longipalpis has very eclectic feeding habits. In nature, it feeds on humans and the on domestic animals such as dog, goat, equine, swine, bovine, chickens, and the on wild animals such as foxes, opossums and rodents. In experimental studies, these species feed on all the animals mentioned above, apart from mice and hamsters (Sherlock \& Guitton 1969, Sherlock 1996). This eclectic feeding habit of the L. longipalpis favours its existence in those ecosystems apparently hostile, such as the caatinga and the consequent dispersion to the en- 
vironments, such as the anthropic areas, granting them ample ecological valence.

The caatinga ecosystem where L. longipalpis and AVL occur, confirms the general definitions of Deane (1956) about the natural ecotopes of this vector.

It is important to emphasize that the eggs and larvae of the L. longipalpis have peculiar characteristics that allow them to survive in dry environments and with certain types of vegetation. According to Feliciangeli et al. (1993), the pores present in the eggs of the L. longipalpis are small and very close to the corion. This characteristic seems important to prevent the desiccation, and favours the survival of the vector in dry environments. This, however, does not favour the viability of the eggs in high humidity conditions, since the water can cover these pores and kill the larva by asphyxia.

According to Pessoa et al. (2002), the number of papilla of the larval spiracles varies among the species, such as the L. longipalpis, which lives in drier environments and those species found in the forest areas, very humid, such as L. migonei and L. whitmani.

Also, the caudal setae of the larva of L. longipalpis shows transversal grooves with small and scarce pores, which probably influences its development in drier environments. The larvae of $L$. intermedia and $L$. whitmani have very small and abundant pores and those of the $L$. migonei, are large and plenty. These species live in areas where the humidity is high (Pessoa et al. 2001).

It is inferred that, by analogy, in areas covered by forests, where the humidity is high and there is water retention by the soil, the L. longipalpis has difficulty to complete its biological cycle. The hot air front that leaves the coast towards the plateau meets the cold air front precisely on the Atlantic Forest, causing constant precipitations on this forestal region. Besides that, the high humidity coupled with high temperatures favours the maintenance of the ecosystem and allows for the survival of some species of phlebotomines such as $L$. whitmani and L. intermedia.

Until recently, for lack of further knowledge about the geographic distribution of the L. longipalpis, it seemed that this species was restricted to areas of mountainous land with rocky appearance, and the existence of seasonal semideciduous forests (Costa et al. 1997). However, the presence of $L$. longipalpis in the littoral zones, at sea level and in the open and ventilated field, demonstrates that the species has ample ecological valence, being adaptable to environments of diverse characteristics, as it was said before.

The rise in the incidence of AVL and its rapid dispersion during the last decades, reaching localities in the coastal zone and in the periphery of the big cities, where the ecological characteristics were previously regarded as inadequate to the distribution of $L$. longipalpis, is, in part, a probable consequence of the drastic predatory modification of the primary ecosystem, mainly caused by deforestation (Sherlock et al. 1996). Moreover, according to this author, only the areas in the south of Bahia, where there still are dense forests and the climate is tropical humid, the AVL has not been registered.
The devastation of the forests, such as what happened with the Atlantic Forest, because of anthropic activities, can favour the expansion of other types of vegetation, such as the caatinga, where the L. longipalpis is strongly adapted.

\section{ACNOWLEDGMENTS}

To the botanists Denise Maria Loureiro and Denise Lima Santana for the collections of the plants and to Antonio Carlos dos Santos and Carlos Gustavo Silva Santos, for the help with the sand flies' collections.

\section{REFERENCES}

Azevedo ACR, Vilela ML, Souza NA, Coelho CAA, Barbosa AF, Firmo ALS, Rangel EF 1996. The sand fly fauna (Diptera: Psychodidae; Phlebotominae) of a focus cutaneous of leishmaniases in Ilhéus, state of Bahia, Brazil. Mem Inst Oswaldo Cruz 91: 75-79.

Cabanillas MRS 1999. Prevalência da Leishmaniose Visceral em Vetores, Reservatórios Domésticos e Silvestres no Municipio de Normandia, Estado de Roraima, Brasil, $\mathrm{PhD}$ Thesis, Instituto Nacional de Pesquisas da Amazônia/ Universidade do Amazonas, Manaus, 200 pp.

Costa AIP, Casanova C, Rodas LAC, Galati EAB 1997. Atualização da distribuição geográfica e primeiro encontro de Lutzomyia longipalpis em área urbana no estado de São Paulo. Cad Saúde Pública 31: 632-633.

Deane LM 1956. Leishmaniose Visceral no Brasil. Estudos sobre Reservatórios e Transmissores Realizados no Estado do Ceará, Serviço Nacional de Educação Sanitária, Rio de Janeiro, 162 pp.

Deane LM, Deane MP 1962. Visceral leishmaniasis in Brazil: geographical distribution and transmission. Rev Inst Med Trop São Paulo 4: 198-212.

Feliciangeli MD, Castejon OC, Limongi J 1993. Egg surface ultrastructure of eight new world phlebotomine sand fly species (Diptera: Psychodidae). J Med Entomol 30: 651656.

Fernandes A 1998. Fitogeografia Brasileira, Multigraf, Fortaleza, $340 \mathrm{pp}$.

Forattini OP 1992. Ecologia, Epidemiologia e Sociedade, Editora da Universidade de São Paulo, São Paulo, p. 291421.

Funasa-Fundação Nacional de Saúde 2002a. Vigilância e monitoramento da leishmaniose tegumentar americana em unidades territoriais-Brasil, 1994-2001. Boletim Eletrônico Epidemiológico, ano 2, $\mathrm{n}^{\circ}$ 5, 7 pp.

Funasa-Fundação Nacional de Saúde 2002b. Leishmaniose visceral no Brasil: situação atual, principais aspectos epidemiológicos, clínicos e medidas de controle. Boletim Eletrônico Epidemiológico, ano 2, $\mathrm{n}^{\circ}$ 6, $11 \mathrm{pp}$.

Galati EAB, Nunes VLB, Rego FA, Oshiro ET, Chang MR 1997. Estudo de flebotomíneos (Diptera: Psychodidae) em foco de leishmaniose visceral no estado de Mato Grosso do Sul, Brasil. Cad Saúde Pública 31: 378-390.

Instituto Socioambiental 2001. Dossiê Mata Atlântica, Ipsis Gráfica e Editora, Brasília, 15 pp.

Novaes AB, José AR 1992. Caracterização da região de mata de cipó no sudoeste da Bahia. In Reflorestamento no Brasil, Universidade Estadual da Bahia, Vitória da Conquista, p. 7-16.

Pessoa FAC, Queiroz RG, Ward RD 2001. External morphology of sensory structures of fourth instar larvae of four neotropical species of phlebotomine sand flies (Diptera: Psychodidae) under scanning electron microscopy. Mem Inst Oswaldo Cruz 96: 1103-1108. 
Pessoa FAC, Queiroz RG, Ward RD 2002. Posterior spiracles of fourth instar larvae of four species of phlebotomine sand flies (Diptera: Psychodidae) under scanning electron microscopy. Mem Inst Oswaldo Cruz 95: 689-691.

Radambrasil 1981. Geologia; Pedologia; Vegetação e Uso Potencial da Terra, Ministério das Minas e Energia, Rio de Janeiro, 65 pp.

Rebelo JMM, Leonardo FS, Costa JML, Pereira YNO, Silva FS 1999. Flebotomíneos (Diptera: Psychodidae) da área endêmica na região dos cerrados, estado do Maranhão, Brasil. Cad Saúde Pública 15: 623-630.

Ribeiro ALM, Missawa NA 2002. Spatial distribution of phlebotomine species in the state of Mato Grosso, Brazil, in the period of 1996 to 2001. Entomol Vect 9: 33-34.

Senra MS, Pimentel PSR, Souza PEFP 1986. Leishmaniose visceral em Santarém, Pará: aspectos gerais de controle; inquérito sorológico de cães e tratamento dos casos humanos. Hiléia Médica 7: 23-32.

Sherlock IA 1996. Ecological interactions of visceral leishmaniasis in the state of Bahia, Brazil. Mem Inst Oswaldo Cruz 97: 671-683.
Sherlock IA, Guitton N 1969. Observações sobre o calazar em Jacobina, Bahia. III. Alguns dados sobre Phlebotomus longipalpis, o principal transmissor. Rev Bras Malariol D Trop 21: 541-548.

Sherlock IA, Santos AC 1964. Leishmaniose visceral na zona de Jequié estado da Bahia. Rev Bras Malariol D Trop 16: 441-448.

Sherlock IA, Maia H, Dias-Lima AG 1996. Resultados preliminares de um projeto sobre a ecologia dos flebotomíneos vetores de leishmaniose tegumentar no estado da Bahia. Rev Soc Bras Med Trop 29: 207-214.

Vexenat JA, Barreto AC, Cuba CAC, Marsden PD 1986. Características epidemiológicas da leishmaniose tegumentar americana em uma região endêmica do estado da Bahia. III. Fauna flebotomínica. Mem Inst Oswaldo Cruz 81: 293301.

Young DG, Duncan MA 1994. Guide to Identification and Geographic Distribution of Lutzomyia sandflies in Mexico, West Indies, Central and South America (Diptera: Psychodidae). Mem Entomol Inst 54: 1-881. 